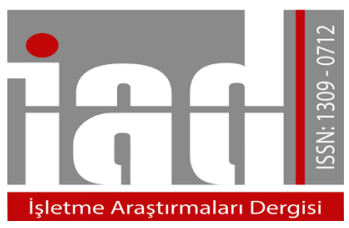

\author{
İşletme Araştırmaları Dergisi \\ Journal of Business Research-Turk \\ 10/4 (2018) 97-114
}

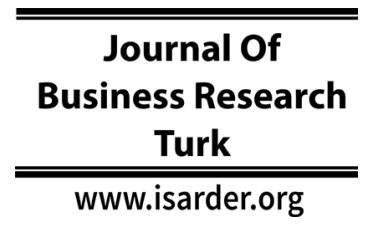

$\underline{\text { Research Article }}$

\title{
Electronic Word of Mouth (e-WoM): Is it an Effective Tool for Re- Vitalizing the Relationship between a Brand and Its Ex-Customers?
}

\author{
Edin Güçlü Sözer \\ Istanbul Okan University \\ Business and Administrative Sciences Faculty \\ İstanbul, Turkey \\ orcid.org/0000-0003-4984-4629 \\ edin.sozer@,okan.edu.tr
}

\begin{abstract}
The target of this study is to shed light into an unexplored area in the marketing literature by (1) identifying the factors contributing to the formation of a relationship revitalization effect of e-WoM in an e-commerce context, and (2) exploring the relationship between re-vitalization effect of e-WoM, current brand loyalty, current brand satisfaction level and old brand satisfaction level. The sample was chosen among the ex-customers of 3 e-retailers in Turkey and 150 customers responded to the survey. Model testing was done through Structural Equation Modeling (SEM) method. Results of the study indicate that re-vitalization of the relationship between the customer and his/her old brand through the e-WoM communication is the function of Tie Strength between the customer and e-WoM message source (sender), the satisfaction level with the old brand before leaving the brand and the brand loyalty level towards the current brand purchased. Brands need to employ e-WoM communication before ex-customers become loyal to their current brand.
\end{abstract}

Keywords: Electronic Word of Mouth (e-WoM), E-WoM Re-Vitalization Effect, Customer Loyalty, Customer Satisfaction.

Received 27 June 2018; Received in revised from 7 November 2018; Accepted 11 November 2018

\section{Introduction}

During the last two decades, both increased competition and demanding consumers created difficult market conditions for the brands which target higher ranks in their markets. New dynamics of postmodern markets have caused conventional communication channels to lose their effectiveness. Brands need alternative tools of communication and persuasion to reach and acquire their target consumer base. While the world experiences an investment recession in conventional media communication, investments in an alternative strategic tool - word of mouth marketing (WoM) - have increased significantly (PQ Media Report, 2008). Marketing professionals and agencies

\section{Suggested Citation:}

Sözer, E.G. (2018). Electronic Word of Mouth (e-WoM): Is it an Effective Tool for Re-Vitalizing the Relationship between a Brand and Its Ex-Customers?, Journal of Business Research-Turk, 10 (4), 97-114. 
react to the new market conditions with the employment of WoM communication activities. As a process of personal influence, brands target to use WoM communication for creating positive word of mouth in favor of their products and services, which in return is expected to create positive reaction of consumers and increase patronage intentions.

The rising penetration of internet usage, as well as social media, has led to the generation of a new type of WoM communication, which is called electronic word-ofmouth or e-WoM (Yang, 2017). Litvin et al (2008) define e-WoM as "informal communication via the Internet addressed to consumers and related to the goods, services or the sellers". E-WoM is effective on spreading the information in internet environment much faster than the conventional WoM communication since it uses online platforms and eventually became an influential source in consumer markets (Abubakar \& Ilkan, 2016).

Even though each year brands increase their investment in word of mouth communication to shape consumer behavior in favor of their brands and consequently to acquire new customers and retain existing customers, there is a need for deeper understanding of the effects of WoM communication by employing academic research. Existing WoM literature includes studies which are mainly focused on its effect in the diffusion of new product and services (Ryan \& Gross, 1943; Brooks, 1957; Arndt, 1967) as well as generating factors (Charlett, et al. 1995; Brown et al.2005) and outcomes (Bansal \& Voyer, 2000; Engel, 1969). There is a need for focusing on the impact of WoM on the re-vitalization of relationship between the brand and its excustomers, which may result in the creation of an effective tool to be used for this purpose. Unfortunately, the lack of studies on the effects of word of mouth communication on the re-vitalization effect and the limited number of studies on the word of mouth communication, have resulted in a lack of well-constructed and empirically supported models of the word of mouth communication - customer relationship re-vitalization.

In this perspective, this study targets to shed light on a unexplored are in the marketing literature by testing a model to (1) identify the factors contributing to the formation of a relationship re-vitalization effect of e-WoM in an e-commerce context, and (2) understand the relationship between re-vitalization effect of e-WoM, current brand loyalty, current brand satisfaction level and old brand satisfaction level.

In the following sections, WoM, customer loyalty and customer satisfaction literature has been reviewed, antecedents and consequences of WoM communication have been determined; conceptual framework and the associated hypothesis have been presented; research methodology has been explained and finally the paper has been concluded with the review and discussion of the results including the explanation of managerial implications.

\section{Literature Review}

\subsection{WoM Communication and Consumer Behavior}

Since the beginning of consumer markets, interactional processes have played an important role in mediating individual behavior of consumers (Darden \& Reynolds, 1971). WoM communication, an important interaction source (Gilly et al. 1998), can be defined as a person-to-person non-commercial conversation about a product, service or 
brand. WoM communication has become the focus point of many researchers for more than sixty years (Brooks, 1957). Studies conducted on the subject mainly focused on the consumer behavior outcomes of WoM, as well as its antecedents.

Many researchers studied the outcomes of WoM communication from diffusion of innovations perspective and reported its positive effect on the adoption of innovations or new products / services (Ryan \& Gross, 1943; Brooks, 1957; Arndt, 1967). WoM communication has been found to be an important factor also in shaping consumer attitudes toward a brand/product/service (Bone, 1995), in the purchase decision context (Arndt, 1967; Bansal \& Voyer, 2000; Sheth, 1971) and in affecting both the perceived risk (Roselius, 1971; Woodside, \& Delozier, 1976; Settle, \& Alreck, 1989) and cognitive dissonance (Engel, 1969; Buttle, 1998) associated with purchase decision.

Another stream of studies focused on the antecedents of WoM communication. The result of the consumer experience with the product or service has been studied as an important antecedent which initiates WoM communication and affects consumer behavior (Charlett, et al. 1995; Brown et al.2005).

A last stream of research area was related with the factors which determine the effectiveness of WoM communication. Considering the e-commerce context, this stream of research can be analyzed in four distinct focuses namely personal, interpersonal, situational and argument quality factors. These factors individually or collectively enhance the influence of WoM on receiver (Yang, 2017; Sweeney et al. 2008).

The first group, personal factors, consists of characteristics of the WoM parties such as sender's perceived expertise, opinion leadership of the sender and expertise level of receiver. Several studies explored and reported the positive relationship between source expertise and WoM effectiveness (Bansal \& Voyer, 2000; Gilly et al. 1998; Bone, 1995; von Wangenheim \& Bayo'n, 2004). On the other hand, several studies focused on the relationship between the expertise level of the receiver and the output of WoM communication (Bansal \& Voyer, 2000 \& Gilly et al. 1998). Results were inconclusive for such relationship. The existence common interest points of receiver with WoM source have been reported as another factor which positively influences WoM effectiveness (Dichter, 1966). Similarly, the opinion leadership of the sender, as another important factor, has been also reported to be effective on WoM communication (Engel, 1969; Barak, 1988; Haywood, 1989).

Some inter-personal factors play crucial role in the operation of WoM communication within a consumer network (Sweeney et al. 2008). Inter-personal factors consist of the degree of social relationship level and similarity between WoM sender and receiver. Several studies focused on the influence of the degree of social relationship - namely tie strength - between the sender and receiver (Bansal \& Voyer, 2000; Granovetter, 1973; Stafford, 1966). Another focus of the studies was on the effect of similarity or dissimilarity - namely homophily or heterophily - between sender and receiver in terms of social background, opinions and preferences in the operation of WoM communication in consumer networks (Gilly et al. 1998; von Wangenheim \& Bayo'n, 2004).

The third group consists of situational factors which derive from the characteristics of the decision context. Such factors include the risk perception of the receiver and level of seeking for WoM communication. Many studies confirm the 
importance of risk perception of the receiver in the effectiveness of WoM communication. Findings show that when the case brings high functional, financial, social or psychological risks, WoM communication plays an important role in the decision-making function (Arndt, 1967; Bansal \& Voyer, 2000; von Wangenheim \& Bayo'n, 2004). Another situational factor is related with the WoM seeking level of receiver. Studies confirm that the effectiveness of WoM communication is higher when such communication is actively sought by the receiver (Bansal \& Voyer, 2000; Gilly et al. 1998).

The last group of factors, argument qualities, consists of message characteristics of e-WoM communication. This group of factors is related with the perception of customers about the quality of information he/she receives as a result of e-WoM communication (Negash, 2002). Bhattacherjee and Sanford (2006) define the argument quality as "persuasive strength of arguments embedded in an informational message". Argument quality construct is composed of relevance of the message, timeliness level, accuracy level, and finally, comprehensiveness. Relevance of the information refers to the availability and being easily accessible (Nah and Davis, 2002). Timeliness level concerns with the current and up-to-date (Madu \& Madu, 2002). Consumers' perception of the correctness of the information plays an important role in their evaluation of eWoM communication. This is reflected with the Accuracy variable (Wixom \& Todd, 2005). Consumers look for more detailed information which will facilitate their decision making on the issue (Sullivan, 1999). Thus, comprehensiveness is another important factor which plays a role in the effectiveness of e-WoM communication.

Review of the existing literature clearly shows that there is a lack of studies which exclusively focus on the effects of e-WoM on relationship re-vitalization of ex-customer of an e-retailer brand and there are no any well-constructed and empirically supported models which explain the phenomenon.

\subsection{Brand Satisfaction and Brand Loyalty}

Three important factors, namely rapidly changing social and economic environment, more sophisticated and demanding consumer population and aggressive competition, force managers to create strong brands in order to cope with these challenges. Being a strong brand requires the delivery of a value, which is superior than those delivered by the competitors, as well as being perceived as unique compared to them. A natural consequence of this is the more favorable reaction of consumers towards the marketing program of the brand (Keller, 1993) and their attitudinal and behavioral loyalty. This unique position of the brand in the mind of consumer is measured by the CBBE construct. Aaker (1991) identified the components of CBBE as "brand awareness, associations linked to the brand, perceived quality, and brand loyalty". CBBE is determined by the strength of these four components in the mind of the consumer.

The most important component of the CBBE, the brand loyalty, can be defined from both behavioral and attitudinal perspectives (Javalgi and Moberg, 1997). Behavioral loyalty is defined as "the continuous purchase of a brand's products and services over a time period" (Yi and Jeon, 2003). Oliver (1997) defines attitudinal loyalty as "the commitment of consumers to rebuy or re-patronize a preferred product or service consistently". When a consumer becomes a loyal customer to a brand, he/she applies filters to the communication efforts of the competitive brands as well to other 
sources in the community and accepts to pay higher price for the brand's products (Mellens et al. 1996). According to Aaker (1996), "a large and loyal consumer base yields future cash flows, which in turn positively affects the value of the business".

To have a loyal customer base, the most critical pre-requisite is the brand satisfaction. Thus, customer satisfaction is a strategic requirement for all customer centric companies (Mittal and Kamakura, 2001). Customer satisfaction is defined as the "customers' overall evaluation of the performance of an offering to date" (Boulding 1990). Fornell (1992) states that the accumulation of these experiences leads to a general judgment about a brand and this in turn supports the creation of the loyalty towards the brand. When customers become satisfied with the brand, they become less sensible to price increases (Anderson, 1996) and show more propensity to spread the positive word of mouth about the brand (Söderlund, 1998). This shows the strong relationship between customer satisfaction and brand loyalty.

\section{Conceptual Framework and Hypothesis}

This present study goes one step further from the focus of the existing literature and aims to identify the contributing factors to the E-WoM Re-Vitalization Effect, as well as its relationship with Old Brand Satisfaction, Current Brand Satisfaction and Current Brand Loyalty.

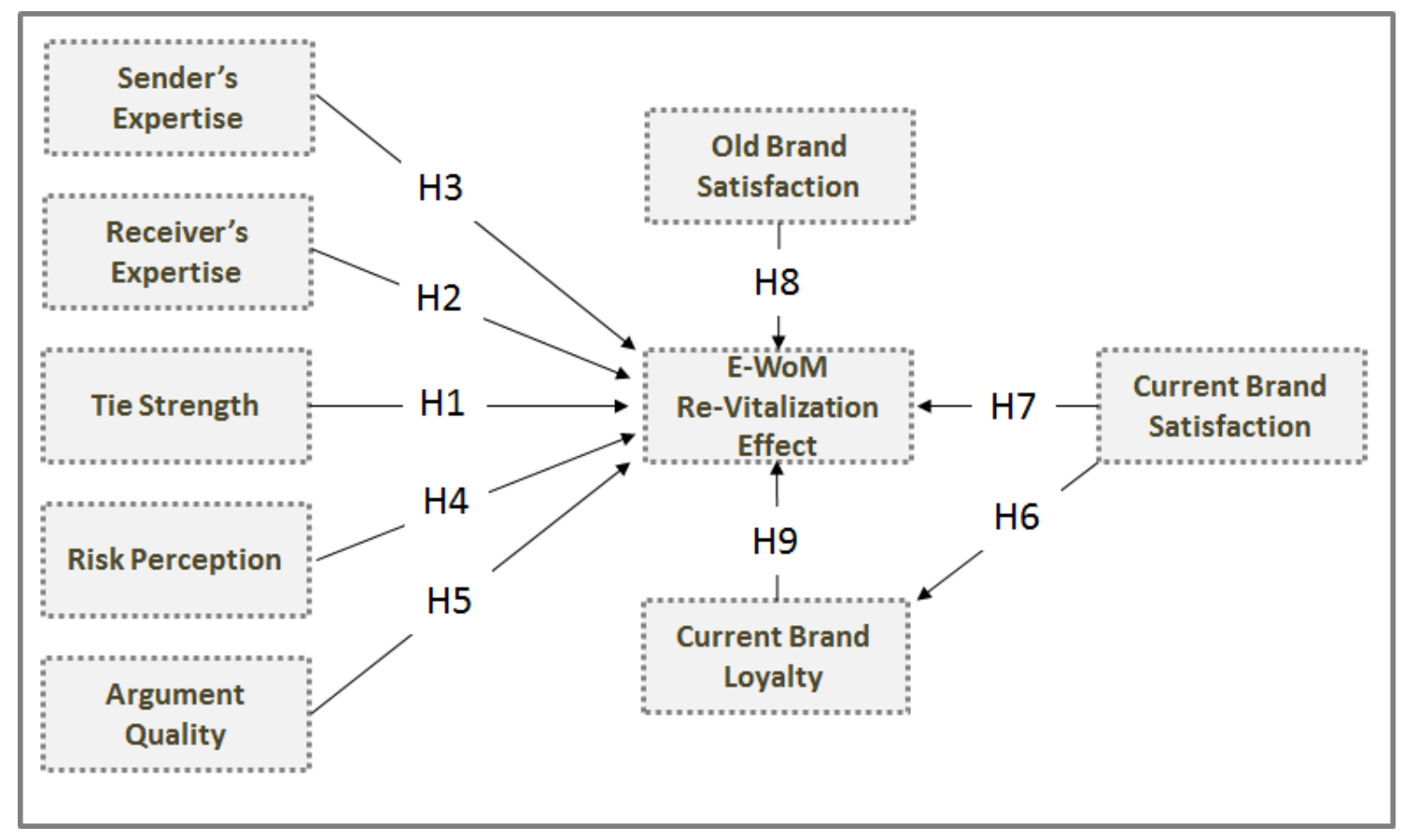

\section{Figure (1). Research Model}

3.1. Factors Contributing to the Re-Vitalization Effect of e-WoM Communication

The proposed research model in this study includes five types of factors which are believed to have a positive relationship with the re-vitalization effect of E-WoM communication.

The first factor in the proposed model, which is called tie strength, shows the relationship level between E-WoM source and receiver. Previous research reports the positive effect of tie strength between source and receiver on the effectiveness of WoM communication (Bansal \& Voyer, 2000; Granovetter, 1973; Stafford, 1966). 
Based on the results of the existing literature, we extend this positive relationship towards the re-vitalization effect of E-WoM communication and present the following hypothesis:

$\mathbf{H}_{1}$. Higher the tie strength between the source and receiver, the higher will be the re-vitalization effect of E-WoM communication.

The second group of factors, namely personal factors, includes receivers' own expertise level on the subject and his/her perceptions related to the expertise level of the E-WoM source (sender). Previous research focused on the relationship between the expertise level of the receiver and the effectiveness of WoM communication. Results of the previous research were inconclusive, and no significant results have been found (Bansal \& Voyer, 2000; Gilly et al. 1998). However, we believe that this relationship still needs further investigation and should be investigated based on re-vitalization effect of e-WoM communication. In this perspective, the following hypothesis is presented:

$\mathbf{H}_{2}$. Higher the expertise level of the receiver on the subject, the lower will be the re-vitalization effect of E-WoM communication.

Previous research reports the positive effect of source expertise on the effectiveness of WoM communication (Bansal \& Voyer, 2000; Gilly et al. 1998; Bone, 1995; von Wangenheim \& Bayo'n, 2004). Based on the results of the existing literature, we extend this positive relationship towards the re-vitalization effect of e-WoM communication and present the following hypothesis:

$\mathbf{H}_{3}$. Higher the perceived expertise degree of the sender, the higher will be the revitalization effect of E-WoM communication.

The fourth factor in the proposed model, Risk Perception, is the overall perception of the receiver derived from the decision context and includes functional, financial, social or psychological risks. Previous research confirms that there is a positive relationship between the risk perception and the effectiveness of the WoM communication (Arndt, 1967; Bansal \& Voyer, 2000; von Wangenheim \& Bayo'n, 2004). Based on the results of the existing literature, we extend this positive relationship towards the re-vitalization effect of e-WoM communication and present the following hypothesis:

$\mathbf{H}_{4}$. Higher the perceived risk of the receiver, the higher will be the re-vitalization effect of E-WoM communication.

The fifth factor, argument quality, is composed of four dimensions including relevancy, actuality, accuracy and comprehensiveness (Cheung \& Thadani, 2012; Xu \& Yao, 2015). Previous research confirms that there is a positive relationship between the level of argument quality and the effectiveness of the e-WoM communication (Cheung \& Thadani, 2012; Xu \& Yao, 2015; Zhang, \& Watts, 2008; Ferren \& Watts, 2008). Based on the results of the existing literature, we extend this positive relationship towards the re-vitalization effect of e-WoM communication and present the following hypothesis:

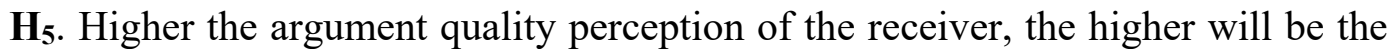
re-vitalization effect of E-WoM communication.

3.2. Relationship between Current Brand Satisfaction, Current Brand Loyalty, Old Brand Satisfaction and E-WoM Re-Vitalization Effect. 
Previous research confirms the positive relationship between the customer satisfaction and brand loyalty in B2C and B2B contexts (Lam et al. 2004; Msallam, 2015; Hallowell, 1996). Customer satisfaction is also found to be effective on the estore loyalty (Anderson \& Srinivasan, 2003; Harris \& Goode, 2004). Based on the results of the existing literature, we present the following three hypotheses:

$\mathbf{H}_{6}$. Higher the customer satisfaction level with the current brand, the higher will be the brand loyalty towards the current brand.

H7. Higher the customer satisfaction level with the current brand, the lower will be the re-vitalization effect of E-WoM communication.

H8: Higher the customer satisfaction level with the old brand, the higher will be the re-vitalization effect of E-WoM communication.

When customers keep having high satisfaction levels, they become loyal customers, and this leads to lower propensity for switching the brand (Reichheld \& Sasser, 1990). Loyal customers have smaller sizes of consideration sets and these customers continue to make their purchases from the same brands (Sambandam \& Kenneth, 1995). Based on the results of the existing literature, we extend this positive relationship towards the re-vitalization effect of e-WoM communication and present the following hypothesis:

H9. Higher the customer loyalty level towards the current brand, the lower will be the re-vitalization effect of E-WoM communication.

\section{Research Methodology}

\subsection{Data}

The sample was chosen among the ex-customers of 3 e-retailers in Turkey and 150 customers responded to the survey and all included into the analysis as a part of the subject group. The research data were collected by using an instrument including fivepoint Likert and bipolar scales which were taken from corresponding literature. The validity and reliability check of the scales were done through confirmatory factor analysis (CFA) and reliability analysis. Testing of the hypotheses in the conceptual model were done through Structural Equation Modeling (SEM) method, a multivariable statistical method (Byrne, 2010). The analysis was conducted using AMOS and SPSS statistics programs.

\subsection{Study Design}

The study consisted of three stages. In the first stage of the study, the first research instrument was distributed to the subject group. Respondents were asked to fill out this questionnaire which was composed of statements measuring customer loyalty scores and customer satisfaction level both for their current e-retailer brand and old eretailer brand.

In the second section of the study, the second research instrument was distributed to the subject group. The instrument of the second section was composed of three parts. In the first part of the research instrument, respondents were presented with one paragraph long case where it was stated that they need to purchase a laptop and they have three different e-retailer brands (Current E-Retailer, Ex-E-Retailer, and Independent E-Retailer). In the second part, respondents were shown a sample customer forum web page which included the evaluations and comments of different customers regarding the three e-retailer brands. Different types of respondent comments were provided in the forum and most of the comments were stating the superior performance 
and service of the customers' ex-e-retailer brand. Finally, in the third part, respondents were asked to fill out the questionnaire by taking into consideration the laptop purchase case and the customer comments on the customer forum web page. Respondents filled out the statements which targeted to identify the factors contributing to the relationship re-vitalization effect of e-WoM communication.

In the third section of the study, respondents filled out the statements measuring the relationship re-vitalization effect of e-WoM communication.

\subsection{Operalization of Variables}

The research model includes the determinants of e-WoM re-vitalization effect including five e-WoM factors, current brand loyalty, current brand satisfaction, and old brand satisfaction.

4.3.1. E-WoM Factors Contributing to the Re-Vitalization Effect of e-WoM Communication

The items are based on previous research and are modified somewhat to better fit the context of the study. Since all the original measurement scales used are in English, statements are translated from English to Turkish and reworded again.

Perceived Expertise was measured with a multi item, five-point semantic differential scale. Although there are several versions of the measure (Tripp et al. 1994), Netemeyer and Bearden's (1992) five item scale was used in this study. The internal reliability measure of the scale is reported as 0.94 (cronbach alpha) by Netemeyer and Bearden (1992).

Tie Strength was measured by several researchers, but in this study Frenzen and Davis's (1990) scale was used. In their study tie strength was measured by 5 items resulting in Cronbach's alpha of 0.93 representing internal reliability. All of the items regarding tie strength were measured using 5-point Likert-type scales.

Perceived Risk variable was measured by employing two different scales which measure financial and performance risks associated with the product. Financial risk was measured by borrowing the scale used by Grewal, Gotlieb, and Marmorstein (1994) which is the modified version of Shrimp and Bearden's (1982) original financial risk scale. Bearden and Shrimp (1982) used a three-item, nine-point scale. Grewal, Gotlieb, and Marmorstein (1994) added the last item to the original study by Bearden and Shrimp (1982). All versions of the scale are reported to be reliable ranging between 0.86 and 0.72 .

Receiver Expertise was measured by employing Netemeyer and Bearden's (1992) five items semantic differential scale. Authors reported 0.94 (cronbach alpha) internal reliability score for this scale.

The scale which is validated by Larasati and Yasa (2017) is used in the measurement of argument quality. Authors reported 0.875 (cronbach alpha) internal reliability score for this scale.

4.3.2. Other Variables (E-WoM Re-Vitalization Effect, Brand Loyalty, Customer Satisfaction)

E-WoM re-vitalization effect construct was measured by adopting the 3 bipolar semantic scale employed by the study of Bansal and Taylor (2002).

A multidimensional scale which is developed and validated by Yoo and Donthu (2001) is used in the measurement of brand loyalty construct. A strong construct 
validity is reported by Yoo \& Donthu (2001). Only statements measuring the brand loyalty were employed in this study.

Finally, customer satisfaction construct was measured by adopting the six items five-point Likert type scale developed by Oliver (1980).

4.3.3. Scale Validity and Reliability

To check the construct validity, Confirmatory Factor Analysis (CFA) was conducted including 29 variable items following the data purification (Anderson \& Gerbing, 1988). CFA resulted in adequate level fit indices including $\chi 2 / D F=1.425$, $\mathrm{CFI}=0.935, \mathrm{IFI}=0.937, \mathrm{RMSEA}=0.059$. The $\mathrm{CMIN} / \mathrm{DF}$ ratio resulted below the threshold level of 3 and all other fit indices including RMSEA were at the acceptable levels (Bagozzi \& Yi, 1990).

Table 1 shows the standardized factor loadings of each 29 variable items. According to the results, factor loadings are satisfactory and all significant.

Table 1. Confirmatory Factor Analysis Results

\begin{tabular}{|c|c|c|c|}
\hline Variables & Items & $\begin{array}{l}\text { Standardized } \\
\text { Factor Loads }\end{array}$ & $\begin{array}{c}\text { Unstandardized } \\
\text { Factor Loads }\end{array}$ \\
\hline \multirow[t]{2}{*}{ Sender's Expertise } & SEX4 & 0.565 & 0.546 \\
\hline & SEX5 & 0.919 & 1 \\
\hline \multirow[t]{3}{*}{ Tie Strength } & TIE1 & 0.897 & 0.916 \\
\hline & TIE2 & 0.941 & 1.005 \\
\hline & TIE3 & 0.944 & 1 \\
\hline \multirow[t]{3}{*}{ Receiver's Expertise } & REX1 & 0.470 & 0.502 \\
\hline & REX2 & 0.700 & 0.759 \\
\hline & REX3 & 0.868 & 1 \\
\hline \multirow[t]{6}{*}{ Argument Quality } & ARG1 & 0.736 & 1.104 \\
\hline & ARG2 & 0.738 & 1.006 \\
\hline & ARG4 & 0.549 & 0.666 \\
\hline & ARG5 & 0.750 & 1.025 \\
\hline & ARG6 & 0.715 & 0.799 \\
\hline & ARG7 & 0.739 & 1 \\
\hline \multirow[t]{5}{*}{ Old Brand Satisfaction } & OSAT1 & 0.762 & 1.574 \\
\hline & OSAT3 & 0.861 & 1.656 \\
\hline & OSAT4 & 0.576 & 1.204 \\
\hline & OSATS & 0.942 & 1.761 \\
\hline & OSAT6 & 0.483 & 1 \\
\hline \multirow[t]{2}{*}{ Current Brand Satisfaction } & SAT3 & 0.877 & 0.868 \\
\hline & SAT5 & 1.016 & 1 \\
\hline \multirow[t]{2}{*}{ Risk Perception } & RIS3 & 1.195 & 1.989 \\
\hline & RIS4 & 0.606 & 1 \\
\hline \multirow[t]{3}{*}{ Current Brand Loyalty } & LOY1 & 0.594 & 0.602 \\
\hline & LOY2 & 0.691 & 0.770 \\
\hline & LOY3 & 0.924 & 1 \\
\hline \multirow[t]{3}{*}{ Revitalization Intention } & REV1 & 0.854 & 0.945 \\
\hline & REV2 & 0.931 & 1.042 \\
\hline & REV3 & 0.924 & 1 \\
\hline$p<0.01$ for all items & & & \\
\hline
\end{tabular}


In addition to construct validity, convergent validity of the scales was also checked by calculating average variance extracted (AVE) values. Table 2 shows calculated AVE scores which are above the 0.5 threshold level except one value, hereby confirming the convergent validity (Byrne, 2010). The comparison between the square roots of AVE scores (diagonals in the table) and correlation of components confirms the discriminant validity of the scales. Additionally, composite reliability and Cronbach $\alpha$ score resulted in acceptable levels are also included in the table confirming the reliability of the scales (Fornell \& Larcker, 1981).

\section{Table 2. Construct Correlation, AVE and Reliability}

\begin{tabular}{|c|c|c|c|c|c|c|c|c|c|}
\hline Variables & 1 & 2 & 3 & 4 & 5 & 6 & 7 & 8 & 9 \\
\hline Sender's Expertise & $(.762)$ & & & & & & & & \\
\hline Tie Strength & -.143 & $(.927)$ & & & & & & & \\
\hline Receiver's Expertise & .163 & -.005 & $(.698)$ & & & & & & \\
\hline Argument Quality & -.072 & -.130 & .039 & $(.707)$ & & & & & \\
\hline Old Brand Satisfaction & -.055 & .060 & $.256^{* *}$ & .173 & $(.744)$ & & & & \\
\hline Current Brand Satisfaction & .068 & -.062 & $.221^{\circ}$ & $.283^{* *}$ & .055 & $(.949)$ & & & \\
\hline Risk Perception & .014 & .067 & .122 & $.335^{* *}$ & .051 & $.268^{* *}$ & $(.947)$ & & \\
\hline Current Brand Loyalty & .047 & .056 & $.305^{* *}$ & .124 & -.166 & $.240^{* *}$ & .024 & $(.748)$ & \\
\hline Re-Vitalization Effect & -.169 & .148 & .007 & .109 & $.314^{* *}$ & -.135 & .049 & $-.449^{* *}$ & $(.903)$ \\
\hline Composite Reliability & .725 & .949 & .730 & .857 & .855 & .947 & .941 & .788 & .930 \\
\hline Average Variance Extracted & .582 & .860 & .488 & .501 & .555 & 901 & .898 & .561 & .817 \\
\hline Cronbach $\alpha$ & .680 & .948 & .709 & .871 & .867 & .943 & .840 & .786 & .929 \\
\hline \multicolumn{10}{|c|}{$\cdots$. Correlation is significant at the 0.01 level (2-tailed). } \\
\hline \multicolumn{10}{|c|}{ - Correlation is significant at the 0.05 level ( 2 -tailed). } \\
\hline Diagonals show the square root & f AVEs & & & & & & & & \\
\hline
\end{tabular}

\section{Findings and Discussion}

Structural Equation Model with maximum likelihood estimation method was used to test the hypotheses of the research study. The evaluation of the structural regression model was made using goodness of fit indices. Goodness of fit indices include the absolute fit indices, $\chi 2$ statistic and the root mean square error of approximation (RMSEA), and, the relative goodness of fit indices, the comparative fit index (CFI) and the incremental fit index (IFI) (Akgün, et al. 2014).

Figure 2 includes the results of the goodness of fit indices which confirm that the model adequately fitted, having the following fit indices values: $\chi 2 / \mathrm{DF} 1.480$, CFI 0.925 , IFI 0.927 and RMSEA 0.063, which is considered having adequate fit when values between .05 and .08 are reported (Browne \& Cudeck, 1993). 


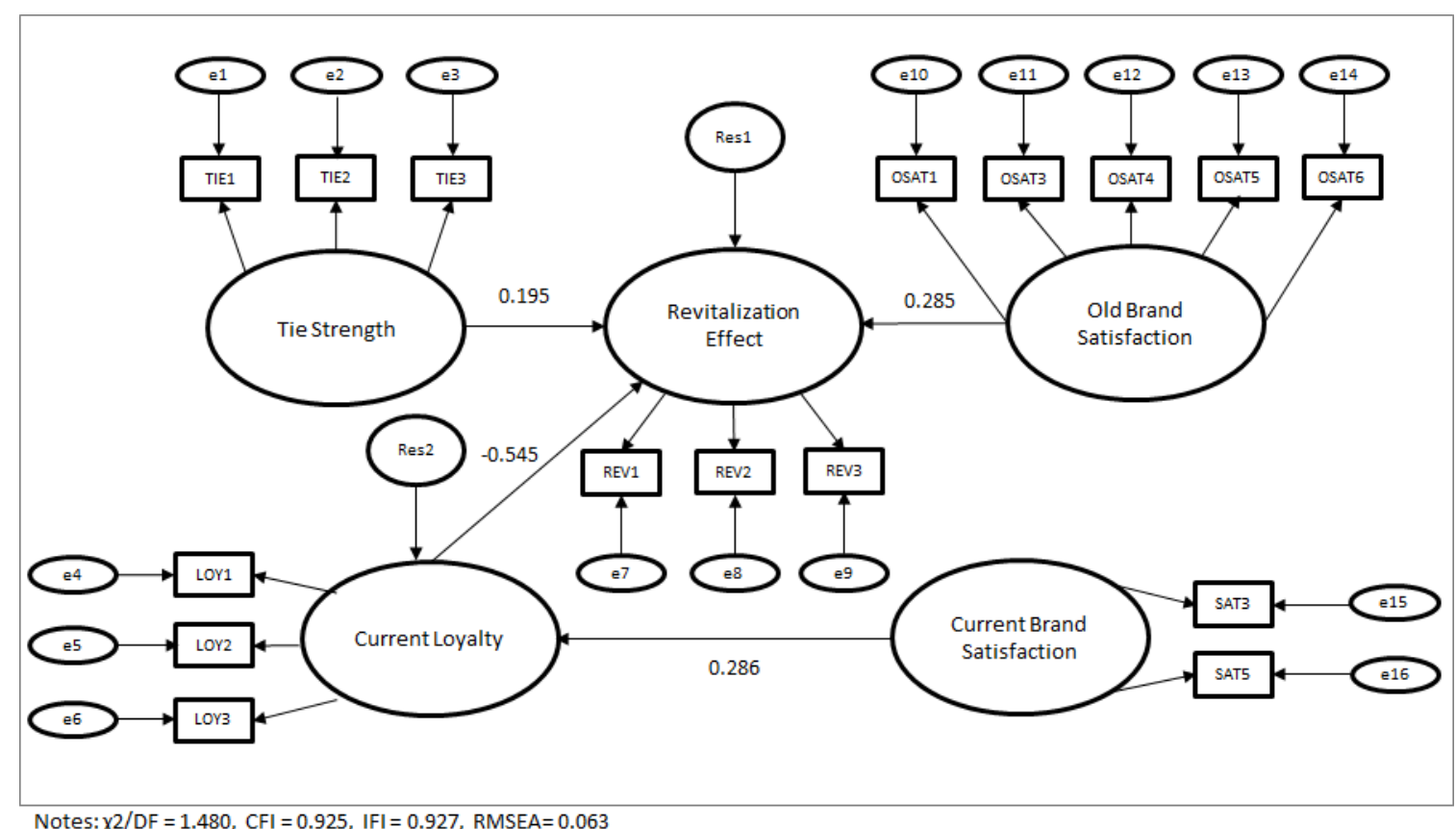

Figure 2. Results of SEM Analysis

Table 3 shows the results of the hypothesis testing with four accepted hypotheses. Statistically significant relationships were reported between Tie-Strength and ReVitalization effect (H1), Current Brand Satisfaction and Current Brand Loyalty (H5), Current Brand Loyalty and Re-Vitalization Effect (H7) and Old Brand Satisfaction and Re-Vitalization Effect (H8).

Table 3. Results of the Hypothesis Testing

\begin{tabular}{|c|l|c|c|c|}
\hline$\#$ & Relationships & $\begin{array}{c}\text { Standardized } \\
\text { Coefficients }\end{array}$ & $\begin{array}{c}\text { Unstandardized } \\
\text { Coefficients }\end{array}$ \\
\hline H1 & Tie-Strength $\Rightarrow$ Re-Vitalization Effect & $0.195^{* *}$ & $0.177^{* *}$ & Result \\
\hline H2 & Receiver's Expertise $\Rightarrow$ Re-Vitalization Effect & 0.035 & 0.049 & Not Accepted \\
\hline H3 & Sender's Expertise $\Rightarrow$ Re-Vitalization Effect & 0.182 & 0.213 & Not Accepted \\
\hline H4 & Risk Perception $\Rightarrow$ Re-Vitalization Effect & -0.091 & -0.078 & Not Accepted \\
\hline H5 & Argument Quality $\Rightarrow$ Re-Vitalization Effect & 0.121 & 0.342 & Not Accepted \\
\hline H6 & Current Brand Satisfaction $\Rightarrow$ Current Brand Loyalty & $0.286^{* *}$ & $0.326^{* *}$ & -0.107 \\
\hline H7 & Current Brand Satisfaction $\Rightarrow$ Re-Vitalization Effect & -0.073 & $0.357^{* *}$ & Not Accepted \\
\hline H8 & Old Brand Satisfaction $\Rightarrow$ Re-Vitalization Effect & $0.285^{* *}$ & Accepted \\
\hline H9 & Current Brand Loyalty $\Rightarrow$ Re-Vitalization Effect & $-0.545^{* *}$ & $-0.707^{* *}$ & Accepted \\
\hline Signif & & & \\
\hline
\end{tabular}

*. Significant at the 0.01 level

The results of the study confirm the positive relationship between Tie-Strength and e-WoM re-vitalization effect in compliance with the previous findings on the relationship between tie strength and effectiveness of e-WoM communication (Bansal \& Voyer, 2000; Granovetter, 1973; Stafford, 1966). On the other hand, testing the relationship between other factors included in the research model and e-WoM revitalization effect did not produce any statistically significant results. Receiver's expertise did not produce any significant effects on e-WoM re-vitalization effect and 
this is in line with the inconclusive results in the literature on the relationship between Receiver's Expertise and E-WoM effectiveness (Bansal \& Voyer, 2000; Gilly et al. 1998). Although existing literature confirms the positive effect of Sender's Expertise, Risk Perception and Argument Quality on the effectiveness of e-WoM communication, a similar significant relationship could not be found in this study between these factors and e-WoM re-vitalization effect. Thus, in the context of the relationship between determinants of an effective e-WoM communication and e-WoM revitalization effect, Tie Strength is reported as the only determinant.

Parallel to the existing literature, the results of the study confirm the positive effect of Current Brand Satisfaction on Current Brand Loyalty (Lam et al. 2004; Msallam, 2015). However, the results did not confirm a statistically significant effect of Current Brand Satisfaction on E-WoM re-vitalization effect. On the other hand, Current Brand Loyalty is found to be negatively effective on the e-WoM re-vitalization effect. This is the extension of the findings in the current literature on the relationship between the brand loyalty and customer retention (Reichheld \& Sasser, 1990; Sambandam\& Kenneth, 1995). Finally, satisfaction from old brand is found to be positively effective on the e-WoM re-vitalization effect. This is also an extension of the previous findings between satisfaction and customer loyalty (Hallowell, 1996).

The results of the study confirm that re-vitalization of the relationship between the customer and his/her old brand through the e-WoM communication is the function of Tie Strength between the customer and e-WoM message source (sender), the satisfaction level of customer with the old brand before leaving the brand and the brand loyalty level of customer towards the current brand purchased. These findings lead to important managerial implications for the brands who wish to re-target their excustomers.

First, the findings of the study clearly indicate that the strength of the relationship between the message source and the customer is an important determinant of the eWoM re-vitalization effect. Thus, brands who wish to re-acquire their ex-customers may think of developing strong referral programs to establish and sustain networked customers to maximize the tie strength effect in case of need for re-targeting the customers.

Secondly, since the positive effect of customer satisfaction regarding the old brand is also a determinant of the effectiveness of e-WoM revitalization, brands should always look for the ways to prevent high level of complaints among the customers who decide to switch the brands. To prevent the total break-up forever and even negative word of mouth, brands should always try to compensate for customers taking into consideration the future re-targeting opportunities and a second chance.

Third, the results of the study confirm the negative effect of the current brand loyalty on the e-WoM re-vitalization effectiveness. On the other hand, another finding shows that there is no significant effect of current brand satisfaction on the e-WoM revitalization effectiveness. These results indicate that once the customer's current brand loyalty is sustained, it is difficult to re-acquire the customer via the e-WoM communication. Another indication of the results is that, when the customer is satisfied with the current brand; this does not affect negatively the e-WoM re-vitalization effect. Thus, brands need to take necessary actions before customers become loyal to their current brands because once the loyalty relationship is established; it may become more 
difficult for old (previous) brands to re-vitalize the relationship via e-WoM communication.

\section{Conclusion}

This study provides important contributions to the marketing literature. However, there is a need to underline some limitations of the study in terms of generalizability. First, there are some limitations regarding the representativeness of the sample. Three eretailer brands are included in the study. An extended number of e-retailers and higher number of subjects may be included into the study to reach to a more representative sample of the population. Moreover, the research is conducted in İstanbul. This may be extended to other cities or geographical areas to increase the representativeness. Another limitation of the study is that it includes only Turkish consumers without any generational perspective. To increase the generalizability, a cross-country and crossgenerational comparison may be included in the future studies to reach at more generalizable results.

\section{References}

Aaker D. 1991. Managing Brand Equity: Capitalizing on the Value of a Brand Name. The Free Press, New York, NY.

Aaker, D. 1996. Measuring Brand Equity Across Products and Markets. California Management Review 38(3), pp. 102-121.

Abubakar, A. M. and Ilkan, M. 2016. Impact of online WoM on destination trust and intention to travel: a medical tourism perspective. Journal of Destination Marketing Management 5, pp. 192-201.

Akgün, A. e., Ince, H., Imamoğlu, S., Keskin, H., \& Kocoğlu, I. (2014). The mediator role of learning capability and business innovativeness between total quality management and financial performance. International Journal of Production Research, 52(3), pp. 888-901.

Al-Msallam, S. (2015). Customer Satisfaction and Brand Loyalty in the Hotel Industry. European Scientific Journal, 1(October 2015 Special Edition), pp. 232-251.

Anderson, E. W. (1996). Customer Satisfaction and Price Tolerance. Marketing Letters, 7 (3), pp. 265-274.

Anderson, R. \& Srinivasan, K. (2003). E-Satisfaction and E-Loyalty: A Contingency Framework. Psychology and Marketing, 20(2), pp. 123-138.

Arndt, J. A. 1967. Word of Mouth Advertising. New York: Advertising Research Foundation.

Ashill, N. J. and Sinha, A. 2004. An Exploratory Study into the Impact of Components of Brand Equity and Country of Origin Effects on Purchase Intention. Journal of Asia - Pacific Business 5(3), pp. 27.

Ayu Larasati, A. and Yasa, N.K. 2017. The Effects of Argument Quality and Sources Credibility on Ewom Credibility and Online Reviews Adoption International Journal of Management and Commerce Innovations 5(2), pp. 892-898.

Bansal, H.S. and Voyer, P.A. 2000. Word-of-mouth processes within a service purchase decision context. Journal of Service Research 3(2), pp. 166-77. 
Bansal, H.S., Taylor, S.F. and James, Y.S. 2005. Migrating to new service providers: toward a unifying framework of consumers' switching behaviour. Journal of the Academy of Marketing Science, 33(1), pp. 96-115.

Barak, B., Stern, B.B. and Gould, S.J. 1988. Ideal age concepts: an exploration in Advances in Consumer Research Volume 15, eds. Michael J. Houston, Provo, UT: Association for Consumer Research, pp. 146-15.

Bearden, W. O., \& Shrimp, T. S. 1982. The Use of Extrinsic Cues to Facilitate Product Adoption. Journal of Marketing Research 19, pp. 229-239.

Bhattacherjee, A. and Sanford, C. 2006. Influence processes for information technology acceptance: an elaboration likelihood model. MIS Quarterly, 30(4), pp. 805-25.

Biedenbach, G. \& Marell, A. 2010. The impact of customer experience on brand equity in a business-to-business services setting. Journal of Brand Management 17(6), pp. 446-458.

Bone, P.F. 1995. Word-of-mouth effects on short-term and long-term product judgments. Journal of Business Research 32(3), pp. 213-223.

Boulding, W. (1990). Commentary on unobservable effects and business performance: Do fixed effects really matter? Marketing Science, 9(Winter), pp. 88-91.

Brakus, J.J., Schmitt, B.H.H. and Zhang, S. 2008. Experiential attributes and consumer judgment. in Schmitt, B.H. and Rogers, D.L. (Eds.), Handbook on Brand and Experience Management, Cheltenham, UK, Edward Elgar, 2008, pp. 174-187.

Brooks, R. C. 1957. Word-of-Mouth Advertising in Selling New Products. Journal of Marketing. 22, pp. 154-161.

Brown, T.J., Barry, T.E., Dacin, P.A. and Gunst, R.F. 2005. Spreading the word: investigating antecedents of consumers' positive word-of-mouth intentions and behaviors in a retailing context. Journal of the Academy of Marketing Science 33(2), pp. 123-38.

Browne, M. W., and Cudeck, R. (1993). Alternative ways of assessing model fit. In K. A. Bollen \& J. S. Long (Eds.), Testing structural equation models (pp. 136-162). Newbury Park, CA: Sage.

Buttle, F.A. 1998. Word of mouth: understanding and managing referral marketing. Journal of Strategic Marketing 6, pp. 241-254.

Chang, H. H. and Liu, Y. M. 2009. The Impact of Brand Equity on Brand Preference and Purchase Intentions in the Service Industries. The Service Industries Journal 29(12), pp. 1687.

Charlett, D., Garland, R. and Marr, N. 1995. How damaging is negative word of mouth? Marketing Bulletin 6: 42-50.

Darden, W.R. and Reynolds, F.D. 1971. Shopping Orientation and Product Usage Rates. Journal of Marketing Research 8, pp. 505-508.

Cheung, C. M. K and Thadani, D. R. 2012. The Impact of Electronic Word of-Mouth Communication: A Literature Analysis And Integrative Model. Decision Support Systems 54(1), pp. 461-470. 
Darden W.R. and Reynolds F.D. (1971). The Multidimensionality of Fashion Innovation, in SV - Proceedings of the Second Annual Conference of the Association for Consumer Research, eds. David M. Gardner, College Park, MD: Association for Consumer Research, pp. 452-458.

De Keyser, A., Lemon, K.N., Keiningham, T. \& Klaus, P. 2015. A Framework for Understanding and Managing the Customer Experience. MSI Working Paper No. 15-121. Cambridge, MA: Marketing Science Institute

Dhruv, G., Gotlieb, J. and Marmorstein, H. 1994. The Moderating Effects of Message Framing and Source Credibility on the Price-Perceived Risk Relationship. Journal of Consumer Research 21 (June), pp. 145-53.

Dichter, E. 1966. How word of mouth advertising works. Harvard Business Review 44(6), pp. 147-160.

Engel, J.F. 1969. Word of Mouth Communication by the Innovator. Journal of Marketing 33, pp. 15-19.

Ferren, C. and Watts, S. 2008. Videoconferencing in the field: A heuristic processing model. Management Science 54(9), pp. 1565-1578.

Fornell, C. (1992). A national customer satisfaction barometer: The Swedish experience. Journal of Marketing, 55 (January), pp. 1-21.

Frenzen J.K. and Davis H.L. 1990. Purchasing Behavior in Embedded Markets. Journal of Consumer Research. 17, pp. 1-13.

Gilly, M.C., Graham, J.L., Wolfinbarger, M.F. and Yale, L.J. 1998. A dyadic study of interpersonal information search. Journal of the Academy of Marketing Science 26(2), pp. 83-100.

Granovetter, M. 1973. The strength of weak ties. American Journal of Sociology 78(6), pp. $1360-80$.

Grewal, D., Levy, M. \& Kumar, V. 2009. Customer Experience Management in Retailing: An Organizing Framework. Journal of Retailing. 85 (1), pp. 1-14.

Hallowell, R. (1996). The relationship of customer satisfaction, customer loyalty, and profitability: an empirical study. International Journal of Service Industry Management, 7(4), pp. 27-42.

Harris, L. \& Goode, M. (2004). The Four Levels of Loyalty and the Pivotal Role of Trust: A Study of Online Service Dynamics. Journal of Retailing, 80, pp. 139158.

Haywood, K. M. 1989. Managing word of mouth communications. The Journal of Services Marketing 3(2), pp. 55-67.

Jalilvand, M, R., Samiei, N., Mahdavinia, S, H., 2011. The effect of brand equity components on purchase intention. International business and management 2(2), pp. 149-158.

Javalgi, R.R.G. and Moberg, C.R. (1997). Service loyalty: implications for service providers, Journal of Services Marketing, 11(3), pp. 165-179. Oliver R.L. (1997). Satisfaction: A Behavioral Perspective on the Consumer. Boston: McGraw-Hill. 
Kanwal, A. \& Lodhi, S. 2015. Relationship between Brand Switching Behaviour \& Customer Satisfaction: A Case of Cosmetic Industry of Karachi. The International Journal Of Business \& Management, 3(11), pp. 49-56.

Keaveney, S.M. 1995. Customer switching behavior in service industries: an exploratory study. Journal of Marketing, 59(2), pp. 71-82.

Keller K.L. 1993. Conceptualizing, Measuring, and Managing Customer-Based Brand Equity', Journal of Marketing, 57, pp.1-22.

Khalifa, M. \& Liu, V. 2007. Online consumer retention: Contingent effects of online shopping habit and online shopping experience. European Journal of Information Systems 16, pp. 780-792.

Lam, Y., Shun \& Shankar, V., Erramilli, K. \& Bvsan, M. (2004). Customer Value, Satisfaction, Loyalty, and Switching Costs: An Illustration from a Business-toBusiness Service Context. Journal of The Academy of Marketing Science, 32, pp. 293-311.

Lemon, K.N. \& Verhoef, P. C. 2016. Understanding Customer Experience Throughout the Customer Journey. Journal of Marketing 80(Nov), pp. 69-96.

Litvin, S. W., Goldsmith, R. E., and Pan, B. 2008. Electronic word-of-mouth in hospitality and tourism management. Tourism Management 29, pp. 458-468.

Madu, C.N. and Madu, A.A. 2002. Dimensions of e-quality. International Journal of Quality and Reliability Management 19(3), pp. 246-58.

McCroskey, J.C., Daly, J.A., Richmond, V.P., \& Cox, B. 1975. The effects of communication apprehension on interpersonal attraction. Human Communication Research, 2, pp. 51-65

Mellens, M., Dekimpe, M.G. and Steenkamp, J.B.E.M. (1996). A Review of Brand Loyalty Measures in Marketing. Tijdschrift voor Economic en Management, 41(4), pp. 507-533.

Michalski, S. 2004. Types of customer relationship ending processes. Journal of Marketing Management, 20(9/10), pp. 977-999.

Mittal, V. \& Kamakura, W. (2001). Satisfaction, Repurchase Intent, and Repurchase Behavior: Investigating the Moderating Effect of Customer Characteristics. Journal of Marketing Research, 38 (February), pp. 131-42.

Nah, F.F.-H. and Davis, S. 2002. HCI research issues in e-commerce. Journal of Electronic Commerce Research, 3(3), pp. 98-113.

Negash, S., Ryan, T. and Igbaria, M., 2002. Quality and effectiveness in web-based customer support systems. Information \& Management 40(8), pp. 757-768.

Netemeyer, R.G., and Bearden, W. O. 1992. A Comparative Analysis of Two Models of Behavioral Intention Formation. Journal of the Academy of Marketing Science 20 (Winter), pp. 49-60.

PQ Media Report (2008). https://www.pqmedia.com. Accessed: 6. May.2017.

Ryan, B. and Gross, N. 1943. The diffusion of hybrid seed corn in two Iowa communities. Rural Sociology 8 (1), pp. 15-24. 
Roselius, T. 1971. Consumer rankings of risk reduction methods. Journal of Marketing 35 , pp. 56-61.

Rose, S. Moria, C, Samouel, P., Hair, N. 2012. Online Customer Experience in eRetailing: An empirical model of Antecedents and Outcomes. Journal of Retailing 88(2), pp. 308-322.

Reichheld, F.F. \& Sasser, W.E. (1990). Zero defections: Quality comes to services. Harvard Business Review, 68(September/October), 105-111.

Sambandam, R. \& Kenneth, L (1995). Switching Behavior in Automobile Markets: A Consideration-Sets Model. Journal of the Academy of Marketing Science, 23(Winter), pp. 57-65.

Schmitt, Bernd H. 1999. Experiential Marketing. New York: The Free Press.

Settle, R.B. and Alreck, P.L. 1989. Reducing buyers' sense of risk. Marketing communications 14(1), pp. 34-40.

Sheth, J.N. 1971. Word-of-Mouth in Low-Risk Innovations. Journal of Advertising Research 11(3), pp. 15-18.

Söderlund, M. (1998). Customer satisfaction and its consequences on customer behaviour revisited: The impact of different levels of satisfaction on word-ofmouth, feedback to the supplier and loyalty. International Journal of Service Industry Management, 9(2), 169-188.

Sweeney J.C., Soutar N. G. and Mazzarol T. 2008. Factors influencing word of mouth effectiveness: receiver perspectives. European Journal of Marketing 42 (3/4), pp. 344-364

Stafford, J. 1966. Effects of group influence on consumer brand preferences. Journal of Marketing Research, 3, pp.68-75.

Sullivan, C. 1999. Marketing the web in other media. Editor \& Publisher 132(9), pp. 30 .

Şahin, A., Zehir, C. \& Kitapçı, H. 2011. The effects of brand experience, trust, and satisfaction on building brand loyalty. Procedia Social and Behavioral Sciences 24 (2011), pp. 1288-1301.

Tripp, C. Jensen, T. D. and Carlson, L. 1994. The effects of multiple product endorsements by celebrities on consumers' attitudes and intentions. Journal of Consumer Research 20 (4), pp. 535-547.

Verhoef, P. C., Lemon, K.N., Parasuraman, A, Roggeveen, A., M. Tsiros, and Schlesinger. L. A. 2009. Customer Experience Creation: Determinants, Dynamics and Management Strategies. Journal of Retailing 85 (1), pp. 31-41.

von Wangenheim, F. and Bayo'n, T. 2004. The effect of word of mouth on service switching. European Journal of Marketing, 38(9/10), pp. 1173-1185.

Wixom, B.H. and Todd, P.A. 2005. A theoretical integration of user satisfaction and technology acceptance. Information Systems Research 16(1), pp. 85-102.

Woodside, A.G. and Delozier, M.W. 1976. Effect of word of mouth advertising on consumer risk taking. Journal of Advertising 5(4), pp. 12-19. 
Xu, Xi and Yao, Zhong. 2015. Understanding The Role Of Argument Quality In The Adoption Of Online Reviews: Empirical Study Integrating Value-Based Decision Anda Needs Theory. Journal of system 39(7), pp. 885-902.

Yang, F. X. 2017. Effects of restaurant satisfaction and knowledge sharing motivation on eWOM intentions: the moderating role of technology acceptance factors. J. Hosp. Tour. Res. 41, pp. 93-127.

Yasin, N. M., Noor, M. N., and Mohamad, O. 2007. Does image of country-of-origin matter to brand equity? Journal of Product and Brand Management 16(1), pp. $38-48$.

Yi, Youjae and Hoseong Jeon. Journal of the Academy of Marketing Science, Vol. 31, 2003 (3), pp.229-240.

Yoo, B., Donthu, N. \& Lee, S. 2000. An Examination of Selected Marketing Mix Elements and Brand Equity. Journal of the Academy of Marketing Science, 28(1), pp. 2195-211.

Zhang, W. and Watts, S. 2008. Online communities as communities of practice: a case study. Journal of Knowledge Management 12(4), pp. 55-71. 